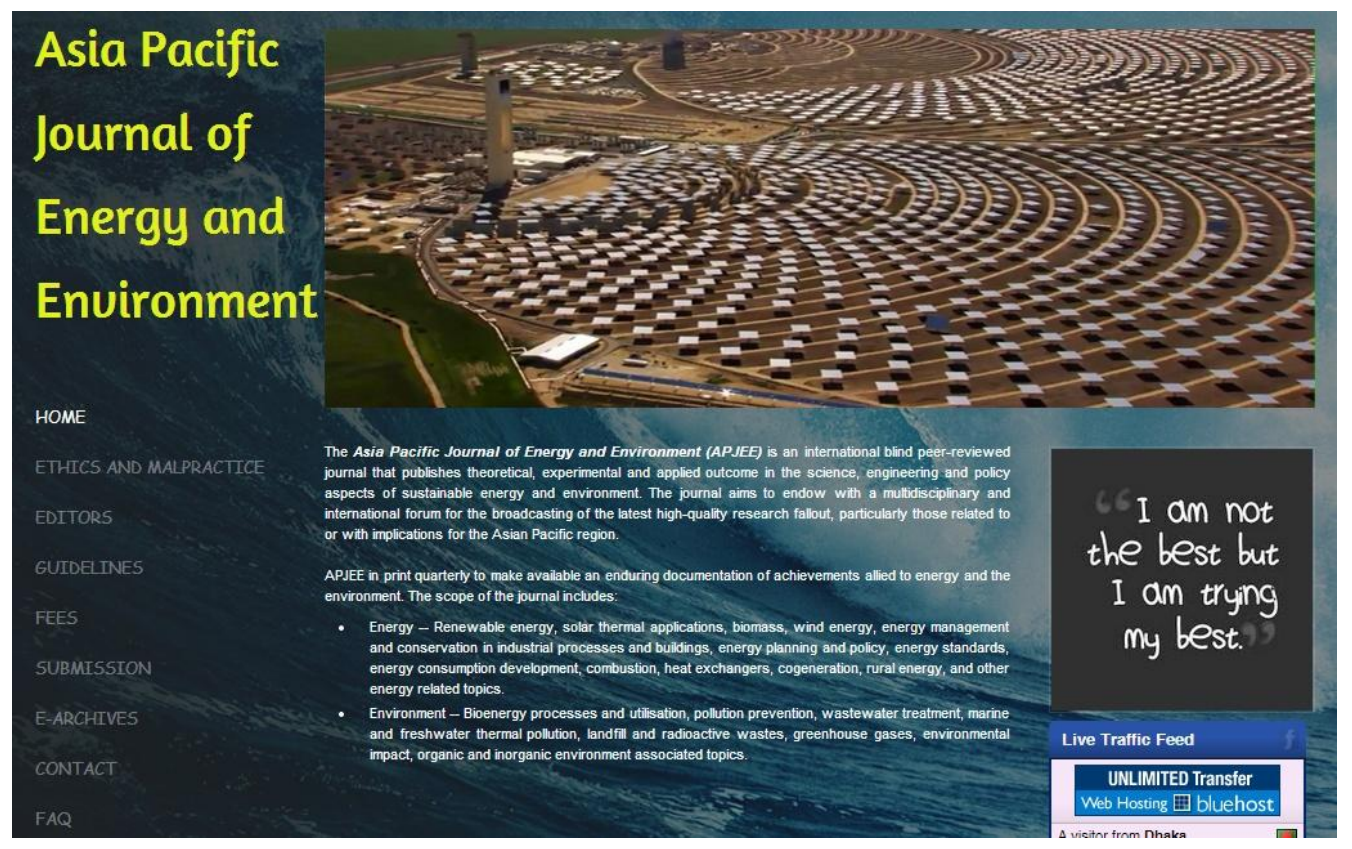




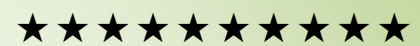

\section{ABO Journals}

- Online Submission

- Peer Reviewed

- Open Access

- Online Archives

- Paperless Review

- Prompt Feedback

- Global Circulation

- International Authorship

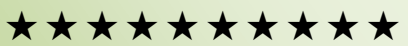




\title{
An Evaluation of Integrated Water Resources Management (IWRM) activities in Bangladesh
}

\author{
Md. Masud Alam ${ }^{1}$; \& Philippe Quevauviller ${ }^{2}$ \\ ${ }^{1}$ Senior Scientific Officer, Water Resources Planning Organization, Ministry of Water Resources, Bangladesh \\ ${ }^{2}$ Associate Professor, Department of Hydrology and Hydraulic Engineering, Vrije Universiteit Brussel, Belgium
}

\begin{abstract}
For resolving adverse impact in water sector (such as severe flooding, sedimentation of river channels, erosion of the riverbanks, scarcity of water during the dry season, saline intrusion and environmental degradation in particular in the Southwest, cyclones and tidal surges in coastal areas, heavy arsenic contamination of groundwater etc.) in Bangladesh, lot of studies and programs have been under taken by the Government of Bangladesh during the last fifty years. Current global climate change and upstream withdrawal of water have made the water related problems more critical. Under these circumstances, water resources management needs more comprehensive and integrated approaches. Early day's water management in Bangladesh were mainly involved to Flood Control Drainage and Irrigation (FCDI) project which caused detrimental effects of other sectors. The issue of Integrated Water Resources Management (IWRM) has been increasingly highlighted after the 1990's. The Flood Action Plan (FAP, 1989-95), Bangladesh Water and Flood Management Strategy (BWFMS, 1995), The Ganges Water Treaty (1996), National Policy for Safe Water Supply and Sanitation (1998), National Water Policy (NWPo, 1999), Guidelines for Participatory Water Management (GPWM, 2000), National Water Management Plan (NWMP, 2004), National Water Resources Database (NWRD, 2001), Regional Technical Assistance (RETA, 2009), Bangladesh Water Act (DBWA, 2013)are the major examples of IWRM practice in Bangladesh.For the evaluation of Integrated Water Resources Management (IWRM) activities in Bangladesh, the three IWRM tools i.e. 'Enabling Environment', 'Institutional Framework' and 'Management Instrument' have been used as a methodology. Lots of Online Questionnaire have been done to the National Water Expertise for getting more information and strengthening the scope of work. Although lot of constraints are existing to develop IWRM plan in Bangladesh, yet the existing policy, plan, guideline, law, institution and information system provide a sound basis for the IWRM implementation in Bangladesh considering the principals of IWRM i.e. efficiency, equity, environmental sustainability. The study has shown that, the progress towards Integrated Water Resources Management (IWRM) in Bangladesh has been good. Much remains to be done. Nevertheless, advancing IWRM is a process of incremental steps and the Bangladesh waterrelated sector is clearly moving in the right direction towards the IWRM plan. Finally the study has drawn recommendations for effective implementation of IWRM activities in Bangladesh.
\end{abstract}

Keywords: Integrated Water Resources Management (IWRM), Global Climate Change, National Water Policy, Flood Action Plan (FAP) 


\section{INTRODUCTION}

Bangladesh is a country of natural disaster. Lot of water related problems are existing here. Among them the flood, sedimentation of river channels, erosion of the riverbanks, scarcity of water during the dry season, saline intrusion and environmental degradation in particular in the Southwest, cyclones and tidal surges in coastal areas, heavy arsenic contamination of groundwater etc are mentionable.

Due to dense population, the sectoral demad (such as agriculture, fisheries, transportation, industries etc.) of water is a very complicated issue for managing water resources in Bangladesh. Water is essential for the country's rich and vulnerable natural ecosystems. Due to future biophysical uncertainties and socio economic uncertainties, water resources management and development in Bangladesh will be a very complex issue Therefore, it is crucial importance for the country to manage this critical natural resource in an integrated and holistic strategic manner.

Lot of studies and plan have been undertaken chronologically by the Government of Bangladesh during the last few decades for systematic Water Resources development and Management. Until mid-20th century, major water-related infrastructure was provided under the zamindar system, whereby the zamindars financed it and collected tax revenues from the local population. Local bodies such as district and union boards supplemented this role. However, the services were inadequate and the Department of Public Health Engineering was established in the 1930s following a series of epidemics related to drinking water. The zamindar system was abolished in 1952.

Following severe flooding in 1954 and 1955, a United Nations Technical Mission (Called Krug-Mission Report 1957) recommended establishing a Water and Power Development Authority. Other recommendations were to: examine the feasibility of embankments along the major rivers, implement smaller flood control, drainage, and irrigation projects, examine the feasibility of a barrage on the Teesta River, raise homestead platforms in flood affected areas, implement zoning to restrict construction of economic infrastructure where flood control could be ensured, and work with other riparian countries to establish better flood forecasting in the common rivers. The then East Pakistan Water and Power Development Authority was created in 1959. (BWDB, Bangladesh-www.bwdb.gov.bd). The preparation of the 1964 Water Master Plan was a major milestone. The Plan envisaged 58 large projects including three barrages on major rivers, with a focus on water for agriculture.

In 1972, the World Bank supported preparation of a Land and Water Sector Study was an achievement. This study promoted a radical shift in strategy from large public-sector flood control and irrigation projects to numerous minor developments using low-lift pumps to irrigate with surface water and tube-wells to irrigate with groundwater.

The country started systematic planning accumulating information on land and water in 1983 which came out as National Water Plan in 1986, updated in 1991. The National Water plan (NWP) was still considered as agriculture focussed plan.

The Earlier Water Management in Bangladesh discussed above were involved mainly to controlling floods and facilitates drainage and irrigation. Those plans were fragmented plans and less importance were given in social and environmental impacts of water resources development.

After the period of 1990's, the issue of IWRM is being highlighting globally. Integrated Water Resources Management is defined as the coordinated development and management of water, land, and related resources in order to maximise economic and social welfare without compromising the sustainability of vital environmental systems. (GWP, 2000). 
A critically important element of IWRM is the integration of various sectoral views and interests in the development and implementation of the IWRM framework. An overview of this process is provided in Figure 1.

Figure 1: IWRM and its relations to sub-sectors

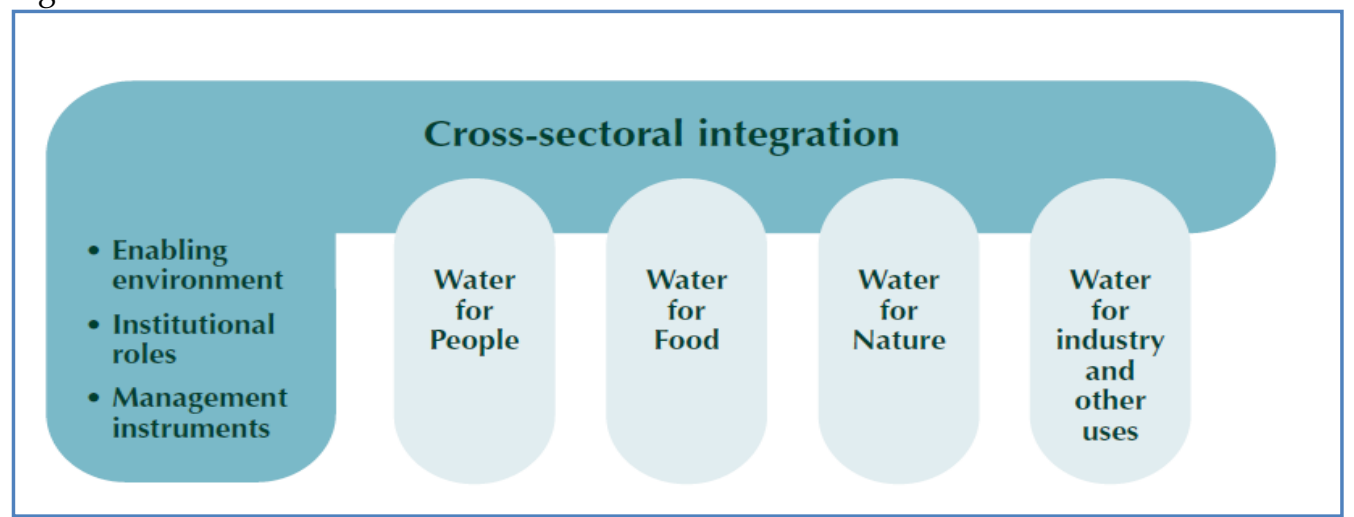

(Source: Technical Advisory Committee (TAC) Background Papers, NO. 4, Integrated Water Resources Management, (CGlobal Water Partnership, SE -105 25 Stockholm, Sweden)

Implementing an IWRM process consists mainly of following the "three pillars" described below: these three pillars are called IWRM tools (GWP IWRM Toolbox, 2001)

- The Enabling Environment

- The Institutional Framework

- The Management Instruments

The Enabling Environment comprises the policies, legislative framework, and financing and incentive structures in Water Management. Institutional Framework is a structure by which policy, strategy and legislation etc. are implemented. Institutions should be open and transparent. It includes both public, private institutions which are directly related and indirectly related in water sector. Management instruments are the elements and methods that enable and help decision-makers to make rational and informed choices between alternative actions.

According to the United Nation Water (The Dublin statement- www.gdrc.org/ uem/water/dublin-statement), the scarcity and misuse of fresh water pose a serious and growing threat to sustainable development and protection of the environment. Human health and welfare, food security, industrial development and the ecosystems on which they depend, are all at risk, unless water and land resources are managed more effectively in the present decade and beyond than they have been in the past.

The Flood Action Plan (FAP) was the pioneer of IWRM plan in Bangladesh. FAP (1989-95) prepared by Flood Plan Coordination Organization (FPCO), financed by 16 major donors, consisted of 26 separate components and was a World Bank coordinated response to the severe flooding of 1987 and 1988. The FAP triggered an unprecedented level of public scrutiny and, in combination with poor results from some FAP evaluation studies, led to the realization that investments in water resource management were unsustainable without meaningful participation by local stakeholder institutions. 
In 1995, Government approved The Bangladesh Water and Flood Management Strategy (BWFMS). The 1995 Strategy proposed a range of structural and non-structural measures to deal with flooding, but more importantly, it set in motion changes in the way the water sector was managed. The Strategy promoted a broader technical approach to water resource planning with more attention to fisheries and environmental considerations. The Strategy also promoted a reduced public sector role and advocated new functions for some key service delivery institutions: The Water Resource Planning Organization (WARPO) and the Flood Plan Coordination Organization (FPCO) merged in 1996 to form a new national water resources planning organization, and a new structure and role were envisaged for BWDB (BWDB act, 2000). Finally, the strategy identified the need for a National Water Policy and a National Water Management Plan guided by that Policy.

The National Water Policy (NWPo) was approved by the Government of Bangladesh in 1999. The NWPo sets out a comprehensive sector goals adopting the principles of integrated water resources management (IWRM). The NWPo through its various provisions emphasises the issues of participatory water management and highlights the importance of stakeholder participation. It recognised that the nation's water resources management should include the protection, restoration, and preservation of the environment and its biodiversity including wetlands, mangrove and other national forests, endangered species, and the water quality. The policy also states that the 'water will be considered an economic resource and priced to convey its scarcity value to all users and provide motivation for its conservation'. (WARPO, Bangladesh- www.warpo.gov.bd).

In parallel to the National Water Policy (NWPo), the Government of Bangladesh has prepared and approved the National Water Management Plan (NWMP) in 2004 which is a strategic and rolling plan and has been prepared following the principles of IWRM. The NWMP is a fundamental departure from the past. The new approach calls for a more holistic and integrated multi-sectoral approach to surface water management focusing the needs of all users. It also called for conjunctive use of both surface and groundwater. In formulation of the Plan a highly participatory approach was adopted, involving widespread public consultation amongst a broad cross-section of water sector stakeholders.

To meet the demand for data and information of the planners, experts, researchers and managers related to water and relevant sector, Water Resources Planning Organization has developed NWRD in 2001 during the preparation of NWMP. The NWRD is the largest geospatial database in the country which holds more than 400 water and related data layers.

During the, World Summit on Sustainable Development in 2002, a number of governments and financing institutions, including the Ministry of Foreign Affairs of the Netherlands, committed financial assistance to encourage institutionalization of changes designed to promote more strategic and coordinated decision-making. The Ministry of Foreign Affaires of the Netherlands made a financial contribution to Asian Development Bank (ADB) for supporting development of IWRM plans in Bangladesh and several other countries. Under this guideline, the Asian Development Bank (ADB) with financial support from the Government of the Netherlands has launched a Regional Technical Assistance (RETA) programme in 2009 to promote effective and efficient preparation of Integrated Water Resource Management (IWRM) plans in Bangladesh. In 2013, the Government of Bangladesh has approved the 'Bangladesh Water Act' (BWA, 2013) after extensive consultation with representatives from all water-using sectors. It was a legal provision to create a Water Act in Bangladesh by National Water Policy (NWPo, 1999). 
This Act has emphasized the optimum use of water resources, water rights and conservation of nature. During the past several decades, Government has consistently worked towards proactive and integrated water resource management with the result that a reasonably comprehensive suite of policies has been put in place. Significant changes have also been introduced to service delivery agencies to promote improvements. In general, the concepts of Integrated Water Resource Management promoted by the Global Water Partnership are well reflected in the development of the water sector in Bangladesh. Nevertheless, as described later in this document, the current study emphasizes selected IWRM aspects and identifies means to further promote IWRM.

The existing policy, law, plan, guideline, institutional framework and database system discussed above provide a good basis for implementing IWRM activities in Bangladesh. There are however still huge gaps in policy, law, plan, institutional framework and database system which hampers an effective implementation of IWRM activities in Bangladesh.

For minimizing the Water related impacts, filling up the gaps in existing policy, plan, law, and institutional framework; database and information system and also to meet up global priority, it is very much necessary to take initiatives for evaluation of country's water resources management activities. This study will critically evaluate the overall challenge in water sector, existing policy, plan, law, institutions, database and information system for sustainable water resources development in Bangladesh based on IWRM tools.

It is now the period of Information Technology and Communication. For getting more information related to IWRM activities ,Online Questionnaire have been done to the National Water Expertise in Bangladesh. The study will show how the knowledge gained from Online Questionnaire can be helpful for setting up appropriate model for sustainable water resources development and management in a developing country like Bangladesh. An Evaluation of Integrated Water Resources Management activity in Bangladesh for sustainable water resources development- based on IWRM tool will be the effective guideline for implementing IWRM principals in Bangladesh for Sustainable development in the country.

\section{OBJective}

The overall objective of this study is to evaluate the existing IWRM activities in Bangladesh for sustainable water Resources Development in the country and to justify whether these activities are worked on the basis of IWRM principles. Lessons will be learned from the National Water expertise and will be incorporated in the country's IWRM guideline for proper implementing IWRM in the country.

Specific objectives include:

- To evaluate the IWRM activities in Bangladesh based on the three IWRM tools (i.e. Enabling Environment, Institutional Framework and Management Instrument). For doing this, operational gaps of existing Enabling Environment (i.e. policies, legislative framework, and financing and incentive structures); Institutional Framework (i.e. organizational framework and the institutional capacity) and Management Instrument (i.e. water resources assessments and management plans, information management and exchange, and conflict resolution) will be identified.

- To set up online questionnaire surveys to the National Water Expertise for getting more appropriate results related to IWRM.

- To set out the guidelines to expose the best way of water resources management system in Bangladesh and for sustainable development. 


\section{APPROACH AND METHODOLOGY}

IWRM toolbox i.e., three pillars (enabling environment, institutional framework, management instruments) designed by Global Water Partnership (GWP) has been used for Evaluating the Integrated Water Resources Management (IWRM) activities in Bangladesh for sustainable water resources development. An online questionnaire survey has been carried out addressing National and International Water Expertise for getting appropriate information related to this work.

\section{SCOPE OF WORKS}

\section{IWRM toolbox:}

\section{$\checkmark \quad$ Related to Enabling Environment}

As discussed earlier, the Enabling Environment comprises the policies, Legislative Framework and financial and inceptive structures.

During the past two decades the Government of Bangladesh has formulated many policies intended to deal with various aspects of water resources management in the context of the National Development Objectives, which aim to (i) alleviate poverty and provide sustainable economic growth, (ii) provide food security, (iii) promote public health and safety, and (iv) protect the natural environment. The major policies which have direct impact on water resources are as follows:

- The National Water Policy (NWPo, 1999)

- National Policy for Safe Water Supply and Sanitation (1998)

- $\quad$ National Environment Policy (1992)

- National Fisheries Policy (1998)

- National Agriculture Policy (1999)

- National Policy for Arsenic Mitigation (2004)

- Coastal Zone Policy (2005) etc.

Setting the appropriate legislative framework is fundamental to effective implementation of the National Water Policy. There are 41 pieces of legislation (NWMP, 2004) in Bangladesh that in some way address the water rights, water quality and water management. The Legislations that are most directly relevant to the Water Resources Management are the followings.

- Groundwater Ordinance (1985)

- Water Resources Planning Act (1992)

- Bangladesh Environment Conservation Act (1995)

- WASA Act (1996)

- Environment Conservation Rules (1997)

- $\quad$ BWDB Act (2000)

- The preparation of the "Bangladesh Water Act", 2013 etc.

Financial and incentive structures in Bangladesh can be described as

- The Annual Development Budget in Bangladesh.

\section{$\checkmark \quad$ Related to Institutional framework}

The Water Sector Institutional framework in Bangladesh can be summarized as the following categories.

\section{- Central Government Water-Related Institutions}


The National Institutions relevant to the water sector comprise some 35 central Government organizations affiliated with 13 different Ministries (NWMP main report 2004). The key National agencies are as follows.

- National Economic Council

- Planning Commission

- National Water Resources Council (NWRC)

- Ministry of Water Resources (MoWR)

- Water Resources Planning Organization (WARPO)

- Joint Rivers Commission (JRC)

- Bangladesh Water Development Board (BWDB)

- Bangladesh Inland Water Transport Authority (BIWTA)

- Ministry of Agriculture

- Department of Fisheries (DoF)

- Ministry of Local Government, Rural Development and Cooperatives (MoLGRDC)

- $\quad$ Ministry of Environment and Forests (MoEF)

- Department of Environment (DoE)

- Soil Research Development Institute (SRDI)

- Bangladesh Haor and Wetland Development Board

- River Research Institute

- Department of Forests

\section{$\checkmark \quad$ Local government Institution}

Various levels of Local government are being established in Bangladesh in accordance with State Policy and recommendations of the local Government Commission. All Local Government institutions come under administrative responsibility of the Local Government Division of MLG\&RDC. Local government institutions are as follows:

- $\quad$ Local Government Engineering Department (LGED)

- Department of Public Health Engineering (DPHE)

- City Corporations:

- Paurashava (Municipalities):

- Zila (District) Parishad:

- Upzila (Thana) Parishad:

- Union Parishad:

\section{$\checkmark \quad$ Other Organizations such as}

- NGOs,

- Academic,

- Private sector,

- Donor Agencies)

\section{$\checkmark \quad$ Related to Management Instrument}

The following principle documents have been taken as Management Instrument tools which help for the decision making in water sector Bangladesh.

- $\quad$ Setting up National Water Management Plan (2004)

- Setting up National Water Resources Database (NWRD)

- Management Information System in WARPO 


\section{Online Questionnaire Survey}

For getting more appropriate results related to IWRM and strengthening this works, a lot of online questionnaire surveys (by email) have been conducted to the National Water Expertise.

Followings are the few reflections about online questionnaire survey on National Water Expertise (Bangladesh).

Dr. Md. Rezaur Rahman, rezaur@iwfm.buet.ac.bd, Professor, Water Resources Planning and Management, Institute of Water and Flood Management (IWFM) of Bangladesh University of Engineering and Technology (BUET), Dhaka 1000, Bangladesh, mentioned: that the reasons for poor implementation of IWRM in Bangladesh are as follows:

Lack of awareness about the need of IWRM - Most senior engineers are not aware of IWRM or not convinced about the need of IWRM. They continuously resist implementation of IWRM.

Political decision makers are also not too aware about IWRM. Technocrats and bureaucrats also fail to enlighten them about the need of IWRM.

In Bangladesh, most of the projects are planned and designed hurriedly in order to fulfil election pledges. There is little time to ensure public participation and carry out SIA/EIA.

The historical engineering biasness of the implementing agencies. The institutional rigidity will continue to hamper IWRM implementation until the new generation of professionals who are exposed to multi-disciplinary education are senior enough and start taking over the decision making process of the agencies.

Scope of corruption with structure oriented solution is more. As a result, building more structures is the preferred option for implementing agencies.

He recommended that The Universities should emphasize on multi-disciplinary education creating a pool of professionals to undertake IWRM challenges and opportunities. The civil societies should continue to advocate for IWRM creating pressure on agencies and decision makers. One success story that can be mentioned in this regard is FAP. Although it started with a technical biasness, at the end, due to persistent pressure from civil societies, the FAP recommendations supported IWRM oriented solutions rather than engineering solutions.

Sultan Ahmed, suahmed@cegisbd.com, Director, Business Development, Administration and Human Resources Development Division, Center for Environment and Geographic Information Services (CEGIS), Bangladesh recommends for Integrated Water Resources Management:

$\checkmark \quad$ Systemic policy, plan, guidelines and law

$\checkmark$ Peoples Participation according the Guidelines for Participatory Water Management (GPWM)

$\checkmark$ Operation and Maintenance of Small Scale Water management Project by Community Group

$\checkmark$ Avoiding cross-cutting issues

Dr. Jahir Uddin Chowdhury, juc@iwfm.buet.ac.bd_, Professor, Floodplain Hydrology, Water Resources Systems Modeling, Integrated Water Resources Management, Institute of Water and Flood Management (IWFM) of Bangladesh University of Engineering and Technology (BUET), Dhaka 1000, Bangladesh, mentioned:

"Multi-objective water resources planning is required to address the needs of public health, livelihoods, agriculture, fisheries, ecology, river morphology, salinity intrusion prevention, navigation, industry and hazard reduction. 
Sustainable water management requires equitable distribution of social costs and benefits of water management projects among stakeholders. Appropriate regulations, standards and guidelines are needed to ensure social justice in the distribution of social costs and benefits of water management projects.

Public participation at all stages of decision making is essential for the promotion of equity and transparency. Creation of enabling environment by the Government is a necessary condition for implementation of this management approach.

Bangladesh is a lower riparian country in the basins of the Ganges, the Brahmaputra and the Meghna. Water regime, ecosystems and water availability in Bangladesh are affected by water use, land use and hazard management activities in upstream areas. Integrated river basin management is essential for the well being of the people of the lower riparian country. This requires cooperative effort by the co-basin countries based on the principles of equity and sustainable development".

\section{Results and Discussion}

\section{$\checkmark \quad$ Related to Enabling Environment}

While setting up Enabling Environment in Bangladesh, it can be shown that the existing policy, Plan, guideline and legislative framework can provide sound basis for IWRM plan in Bangladesh.

Among the policies, the NWPo (1999) is the major policy in water sector Bangladesh which holistically advocates for social equity, conservation of natural environmental and efficiency of water management which are the basic components of IWRM.

The Government of Bangladesh has prepared the Bangladesh Water Act (BWA, 2013) which was a legal provision by National Water Policy (NWPo, 1999). This Act has emphasized the water rights, optimum use of water resources, and conservation of nature. The Annual Development Budget in Bangladesh mainly describes the two kinds of Expenditure: i) Capital expenditure, ii) Development expenditure. The Capital expenditure provides the salary and contingency expenditure of the Employee of the state. The development expenditure provides the country's development program including Water Resources. The Development Budget describes the financial resources mobilization which includes grants, internal sources, loans and equity. The Annual development Budget in Bangladesh starts at the month of July in every year and finish in June of Next year. (Annual development budget in Bangladesh (www.bengaliwiki.com/page/Development+Budget)

Still lots of gaps have been identified while reviewing the Enabling Environment in Bangladesh.

Article 2 in NWPo mentioned that, NWPo will be reviewed periodically and revised as necessary. NWPo has not reviewed during the last 12 years. Many situations have been changed during this time. The policy did not coin the term IWRM explicitly. It did not give any clarification about the coastal water. The policy also did not clarify the organizational structure for trans-boundary water management and hydrological region basis water management. The NWPo also did not highlight about the climate change impact issue.

It is also noted that many of other existing policies (fisheries policy, agricultural policy etc.) which have impact on water system are beyond 2000. Under the suggestion of National Water Policy, the Bangladesh has prepared the 'Bangladesh Water Act-2013'. However, the regulatory body to implement this act has not yet been established. 
Most of the Annual Development Budget (ADB) in Bangladesh expends during the month of April to June which is the pre monsoon season. Due to lack of quick resource mobilization along with upcoming monsoon activity of budgetary year, many water resources development activities hamper. Also due to lack of proper coordination, many cross-cutting issues still exist in Water Resources Development project in Bangladesh. The monitoring system is not so strong due to lack of physical infrastructure. In many cases, the government has to depend on foreign loan and grant for development project.

\section{$\checkmark$ Related to Institutional framework}

While setting up appropriate Institutional framework in Bangladesh, it has shown that the core organizations which have central role in the Integrated Water Resources Management activities in Bangladesh according to their priority have Lots of drawbacks in their management and Organizational structure. The integration between the core water management organizations is very limited.

WARPO, which is responsible for macro-level water resource planning in Bangladesh. has not permanent office building. There is an extreme shortage of manpower in WARPO. The service rule for the WARPO professionals is quite inadequate. Job facilities such as promotion, pension and other facilities are under severe constraint. WARPO is now centrally located in Dhaka. It has no regional offices for competent authority for each hydrological region. Existing staffing structure, strength, support and service of WARPO are not sufficient to commensurate with its mandate and redefined functions effectively. But, the professionals of WARPO are attempting to complete their committed assignment with strong and appreciable confidence amid severe limitations.

Bangladesh Water Development Board (BWDB) is responsible for implementing all major surface water development projects and other FCDI projects with command area above 1000 hectares. But there are lots of gaps in BWDB management issue. Among them the conflicting of power exercise between BWDB and Ministry; shortage of manpower; constraining of operational budget for emergency work such as river erosion mitigation; lack of communication skill; slow rate of internal management system; lack of upzilla level office for local water resources development; inadequate service role for BWDB; absence of trained personnel in appropriate place, lack of proper management Information system (MIS) are mentionable.

Department of Environment (DoE) Within MoEF, is mandated to regulate and enforce environmental management including control of water pollution and to ensure that Environmental Impact Assessments are adequate. But DoE is also suffering for shortage of manpower. There are not regional offices at every district level. Other drawbacks include: inadequate service role and promotion, lack of coordination to other organizations.

Local Government Engineering Department (LGED) is located within the Local Government Division. According to the NWPo, 1999, the Local Government will implement FCDI projects having a command area of 1000 hectares or less after identification and appraisal through an interagency Project Appraisal Committee. LGED have few problems: Political biasness, shortage of manpower, inadequate service role and promotion, lack of coordination to other organizations.

Currently the Department of Public Health Engineering (DPHE) is most important government body dealing with water supply and sanitation, responsible for planning, designing, and implementing water supply and sanitation services in rural areas, and in urban areas outside Dhaka and Chittagong. DPHE is also responsible for Arsenic Mitigation in Bangladesh. (www.dphe.gov.bd)DPHE is mostly supply driven and does 
not respond well to user need. Lack of ownership by the end users tends to hinder sustainable operation of the systems.

Each City Corporation is a corporate body which is responsible for raising taxes and other income. City Corporations of Dhaka and Chittagong are supported by Water Supply and Sewerage Authorities (WASAs) formed in accordance with the 1996 WASA Act.WASA is a corporate body under the authority of the Water Supply Wing of the Local Government Division and responsible for provision and up-keep of potable water supply, sewerage and storm drainage. The WASAs are allowed to levy tariffs and fees at rates the Government Approves. WASAs are suffering for lack of sufficient autonomy to take important decisions on planning, implementation, tariff, staffing and other aspects of water supply and sanitation service. Tariffs have to be approved by central government and do not reflect the cost of water production.

Dhaka WASA is facing a serious water shortage. Over-exploitation of groundwater has reached critical levels and is causing serious environmental problems. Surface water in rivers is heavily polluted from industrial and domestic wastes. However, several projects to increase water supplies are being studied.

Local and International NGOs are providing goods and service normally associated with the public and private sectors. The NGOs are playing significant role in environment and water management planning. The private sector is closely involved in all aspects of water resources development and management by consulting, contracting, supplying equipments and training the agencies. Private sector activities have expanded significantly over the last 20 years and they are particularly active in minor irrigation, rural water supply and sanitation. But there is a lack of coordination between the Public, private sector and NGOs.

The World Bank, the Asian Development Bank and numerous bilateral development agencies, notably the Dutch, Danish, Japanese, British and Canadian have been active for many years in financing water development projects with technical assistance and capacity building. UNDP and other United Nations Agencies especially UNICEF, are active in support of water sector programmes and rural development. Proper monitoring is quite inadequate in case of donor funding projects.

Academia is also active in the water management. But due lack funding and technology, advance research activities such as in rainwater harvesting, conjunctive use of rainwater, ground water and surface water etc. are quite inadequate.

\section{$\checkmark \quad$ Related to Management Instrument Analysis of National Water Management Plan (NWMP)}

The National Water Management Plan (NWMP) was intended to translate the National Water Policy into an operational strategy. The Plan, which has a 25 year planning horizon, presented 84 programs grouped into 8 clusters (Appendix III) with an indicated cost of $\$ 18$ billion. The clusters are: Institutional Development (ID), Enabling Environment (EE), Main Rivers (MR), Towns and Rural areas (TR), Major cities (MC), Disaster Management (DM), Agriculture and Water Management (AW), Environment and Aquatic Resources (EA). The objectives of NWMP are: Rational management and wise-wise of Bangladesh's water resources; peoples quality of life improved by the equitable, safe and reliable access to water for production, health and hygiene; Clean water in sufficient and timely quantities for multi-purpose use and preservation of the aquatic and water depended ecosystems. The overall objectives of the NWMP are to contribute in a balanced fashion to the overall national goals of economic development, poverty alleviation, food security, public health and safety, decent standard of living for the people and protection of the natural environment. 
The NWMP is a framework and rolling plan which provides a firm plan for the first five years, an indicative plan for the subsequent five years and perspective plan for the long term (25 years), all set in the context of what may happen at least 50 years ahead.

The NWMP has to be reviewed and updated every five years and WARPO is responsible for monitoring progress and updating programs of the NWMP. WARPO recognizes that the implementation status of the NWMP provides, among other things, an important baseline for updating the NWMP. Accordingly, WARPO requested 11 water-related Government agencies for the status of work that had been carried out in relation to the NWMP. Only BWDB and LGED responded. Many of these agencies have their own sector development plans and monitor their work against those plans. As well, WARPO has not been proactive in pursuing this information in part because of staff limitations and has little authority to require that the information be provided.

There are also few gaps in planning process. NWMP was approved in 2004 providing the firm plan (2000-2005), indicative plan (2005-2010) and long term plan (2010-2025).Noted that, the Plan has approved in 2004, but the firm plan has been shown as 2000-2005, which is unrealistic. And capacity building of few core departments (DPHE, JRC, WASA's) has been overlooked. Water tourism did not include in NWMP. Less emphasis has been given on coastal water in Bangladesh. NWMP did not coin the IWRM tools explicitly. It is too late to review and implementation of NWMP.

The Plan suggested that maintaining Government funding at current proportions of GDP would be sufficient to finance any of the short term (through 2005) Plan scenarios. However, to maintain targets through the medium term (2010), Government would need to more than double its contribution as a proportion of GDP, or identify alternative sources of funding. Due to lack of physical resource, it is very difficult to search alternative source of funding.

There are lots of Knowledge gaps in NWMP in some fundamental issues that have impact on medium and long-term planning, and further research is urgently needed. Knowledge gaps that have been identified in NWMP are as follows:

- Climate Change

- Arsenic in groundwater

- Groundwater utility

- Natural Environmental water requirement

- Long- term implication of water management (Transboundary water issue)

- Developed and decentralised water management

- Promotion of private sector participation

While updating process of NWMP, the provision should be kept for filling the above gaps which is an essential and integrated component of the NWMP plan.

The IWRM tools are the effective tools for the better and sustainable water management practice in a country. Among the existing policy, plan and legislation activities in Bangladesh, the preparation of National Water Policy (NWPo 1999) and the National Water Management Plan (2004) were the major milestone in Water sector Bangladesh which reflect the overall IWRM principal for the country's managing water resources comprehensively. Therefore, along with other policy, plan and act, the more emphasis has been given to National Water Policy (NWPo 1999) and the National Water Management Plan (2004). 
Analysis of National Water Resources Database (NWRD)

As per National Water Policy (NWPo-1999), WARPO is mandated to maintain, update and disseminate the National Water Resources Database. To meet the demand for data and information of the planners, experts, researchers and managers related to water and relevant sector, Water Resources Planning Organization has developed NWRD in 2001 during the preparation of NWMP. The data contained in NWRD has been collected from a wide range of sources (WARPO receives data from 35 agencies) and organized into a relational database format. The NWRD has become the largest geo-spatial database in the country. NWRD is a systematic database, and is established as a national level data provider. The existing network of stations for rainfall, evaporation, discharge, sediment transport and water quality of Bangladesh meets the standards of the World Meteorological Organization (WMO) 1974.

A total of 406 data layers are available in NWRD as of February 2008 , which have been categorized into three level hierarchies, i.e. data group, data type and data layer. Most of the data layers in NWRD are spatial data, time series data and attribute data. The data groups include Base Data, Surface Water, Groundwater, Meteorological, Soil and Agriculture, Forest, Fisheries, Socio-Economic, Environment, Images, Document and Report.

NWRD is a helpful information tool for water resources decision making. Integrated Coastal Resources Database (ICRD) has also been established in WARPO in 2005 which is a subset of NWRD. ICRD database emphasizes on integrated coastal zone database.

Updating and maintaining the National Water Resources Database (NWRD) is one of the core function of WARPO. But lot of gaps are still existing in NWRD. Most of the data in NWRD have been collected before 2000. Some gauge stations are not functioning. Many important data layers are absent. NWRD is not fully web enabled. There is a restriction for online access of data. No revenue budget is available for purchase of updated data. Till now, NWRD is updating by project basis. WARPO has done Memorandum of Understanding (MoU) with few organizations such as LGED, BWDB, CEGIS etc. But more Memorandum of Understandings (MoUs) are needed for easy access of data.

Of late, WARPO is updating NWRD by Water Management Improvement project (WMIP) project. This project has started on 2007 and will finish on 2014. NWMP recommended one programs under the enabling environment cluster. The program is EE007-'NWRD Improved Data collection and Processing facilities' which recommends for the stakeholder consultation, principal of common standard, data pricing policies and one stop data retrieval.

\section{Analysis of Management Information System}

Water Resources Planning Organization has prepared a Management Information System (MIS) under WMIP Project. It is not fully functionalized still now. Lot of Works has to be done under MIS system.

\section{Related to Online Questionnaire Survey}

National Water Expertise highlighted that the major obstacle for IWRM in Bangladesh are the lack of coordination with co-riparian countries, lack of information and awareness, lack of political willingness, lack of organizational smoothness etc.

Questionnaire survey has also shown for Proper implementation of IWRM, information, coordination and stakeholder participation is must. University can play a vital role in this regard. 


\section{CONCLUSIONS AND RECOMMENDATIONS}

\section{Conclusion}

Systematic instruments such as Enabling Environment, Institutional Framework and Management Instruments are crucial for development and management of water sector in Bangladesh which is fully devoted of public goods. As the issue of IWRM has been being highlighting globally after the 1990 period, from the same time the country has achieved a lot of advantage and knowledge in compliance with IWRM guideline. Although the existing policy, plan, guideline and law did not match accurately with IWRM pillars, yet the existing policy, plan, guideline and law provides a sound basis for the IWRM implementation in Bangladesh considering the principals of IWRM i.e. equity, efficiency, environmental sustainability.

Lot of conflict arises in water resources planning. With the supporting of WARPO, the National Water Resources Council, the apex-level decision-making body in Bangladesh provides an excellent institutional framework to ensure that decisions affecting water resources cut across sectoral-lines and to the extent practicable, reflect the interests of all stakeholders.

The study has shown that, In spite of constraints to develop IWRM plan in Bangladesh, the progress towards integrated water resources management in Bangladesh has been good. Much remains to be done. Nevertheless, advancing IWRM is a process of incremental steps and the Bangladesh water-related sector is clearly moving in the right direction towards the IWRM plan.

\section{Recommendations}

Although Bangladesh has achieved lot of progress in IWRM activities, but for minimizing these gaps and for meeting up the future water related socio economic and environmental challenges, the revision is needed the existing policy and plan. Regulatory framework has to be established for implementing the Bangladesh Water Act 2013; Cross cutting issue should be avoided. Budgetary year can be changed from July-June to January -December for avoiding Monsoon and pre-monsoon activities. Also resources mobilization should be quicker. The Government should depend on internal source of money, should search foreign grant but should avoid foreign loan step by step. For emergency action of river erosion and flood control, the emergency budgetary allocation should be quicker. The Joint River Commission, Bangladesh should convey it's endeavor to continue dialogue and research program and study amongst the co-riparian countries ( India, Nepal, China, Bhutan, Mayanmar) for long-term basin wide Planning and Management of Water resources.

WARPO has to work as a center of excellence with the help of competent Authority for awareness building and coordination. Under this circumstance, WARPO has to be strengthened by filling it's gaps. WARPO along with Universities and research Organizations should research about IWRM and any technical issue related to Water Sector. Feasibility study of the adaptation of new technologies should be carried out by WARPO with the help of universities and research organizations. By establishing Central Water Resources Training Unit, WARPO has to promote IWRM professionalism. WARPO should take help from Newspaper and Media by publishing the IWRM activities in Bangladesh. Special attention has to be given on physical infrastructure development in Bangladesh such as implementation of Ganges Barrage, Brahmaputra Barrage and Meghna barrage designated by NWMP. Information and Communication structures such as internet, fax has to be developed by the country for proper implementation of IWRM. Bangladesh Water Development Board (BWDB), Department of Public Health Engineering 
and WASAs along with Technical Universities of Bangladesh have to take collaborative research Plan for long-term research and management of groundwater utility.

Proper research and study is needed for investigate climate change impact in Bangladesh. DoE, Technical Universities, CEGIS along with WARPO have to take initiatives for indepth study of Climate change impact issue in Bangladesh. One of the major competent of IWRM is the environmental sustainability. Lot of gaps exists in this regard. Hence more study is needed for natural environment, aquatic ecology and in-stream water demand in Bangladesh. Bangladesh Haor and Wetland Development Board (BHWDB) have to play a vital role in this regard with the cooperation of WARPO, CEGIS and University.

Collaboration between BADC, DAE, BWDB, LGED and WARPO has to be increased because, BADC and DAE etc are the major agricultural departments which play vital role in sector by using the water (both surface and groundwater) in irrigation. At present the administrative departments are centrally organized, seldom respond to user needs and demands, emphasizing construction rather improving services, and have insufficient dialogue and coordination. Step by step the country has to adopt the decentralized water management and promote private sector participation. Environmental and social Impact and water related hazards have to be minimized by designated organizations. Such as flood and drainage congestion will be managed by BWDB; cyclone will be managed by LGED etc. NWRC has to be strong for conflict resolution in water sector Bangladesh.

Proper implementation of NWMP is pre requisite for sustainable water resources development in Bangladesh. WARPO has to monitor the NWMP meticulously. NWMP has to be updated by considering it's knowledge gaps and other emerging issues. NWMP programme should be linked with IWRM tools. WARPO has to update the NWRD by continuous revenue and development budget. the data pricing policy has to be enacted as law; Stakeholder participation including training of NWRD is necessary. WARPO should do Memorandum of Understanding (MoU) to all data providing agencies. NWRD has to be fully web enabled. And finally 'The draft data dissemination Policy' has to be enacted without further delay.

Information is one of the central parts for Integrated Water Resources Management (IWRM). Along with NWRD, WARPO has to be established and maintained the central Management Information System (MIS) on IWRM. WARPO has to ensure Revenue budget and skilled personnel for maintaining MIS.

Comprehensive development and application of Modeling and GIS is necessary for controlling flood, the river erosion and river siltation for both main and the local river. Mixture of river training and dredging works has to be taken. All this have to be achieved in as cost-effective manner. Strengthening of BWDB is must for implementing this program. Coastal zone has to be managed in integrated way by considering the issue of tidal surge, cyclonic surge, salinity intrusion and drainage congestion. Coastal afforestation along the foreshore is necessary for protecting the tidal surges. Also building upon comprehensive cyclone shelter along the coastal belt and improving the performance of coastal embankment may be the solution of coastal belt. Adequate upland flow has to be ensured for managing the salinity in coastal zone. Lack of fresh water in coastal zone is a problem. Hence alternative source of drinking water can be considered such as bottled water etc.

Emphasis has to be given on drinking Water quality and human health. As the Groundwater is the main source for drinking water in Bangladesh so, the arsenic, iron, boron etc on groundwater supply should be kept in tolerable limit designed by World Health Organization (WHO). In case of surface water, the quality of drinking water must maintain the WHO standards. WASAs and DPHE have to play vital role in this regard. 
For further advanced study of IWRM activities in Bangladesh, the monitoring based evaluation of performance of IWRM activities in Bangladesh and NWMP is necessary. Indepth study is needed to investigate the institutional performance of all water related institution in Bangladesh. It is also necessary to analyze all the ongoing and completed water related project activities in Bangladesh. Also in-depth study and research is necessary for all the IWRM tools. Lessons can be incorporated from other developed countries (such as Australia, US etc.) and other river commission such as the 'Mekong River Commission' (MRC), the 'Murray-Darling Basin Authority (MDBA)' etc. In-depth research study is needed for regional center of excellence. More Focused has to be given on Global Climate Change.

\section{REFERENCES}

[1] MoWR, 1999. National Water Policy, Ministry of Water Resources, Government of the People's Republic of Bangladesh.

[2] WARPO, 2001b. National Water Management Plan, Vol.1: Summery Report, Vol.2: Main Report, Water Resources Planning organization, Ministry of Water Resources, Government of the People's Republic of Bangladesh.

[3] IWRM.Net, 2011. Research projects

[4] MoWR, 2013. Bangladesh Water Act, Ministry of Water Resources, Government of the People's Republic of Bangladesh.

[5] MoE\&F, 1995. The Bangladesh Environment Conservation Act, Ministry fo Environment and Forest, Government of the People's Republic of Bangladesh.

[6] ADB-RETA, 2009. Regional Technical Assistance Supporting IWRM ( Bangladesh),Water Resources Planning organization, Ministry of Water Resources, Government of the People's Republic of Bangladesh.

[7] United Nation Water, 1992. The Dublin statement- www.gdrc.org/ uem/water/dublinstatement

[8] Chowdhury, J.U. (2011), Integrated Approach and Equity Principles to promote Sustainable Water Management in Bangladesh, IWFM, BUET.

[9] Ahmed, S. (2008), Integrated Water Resources Management: From Policy to Practice through a Comprehensive NWMP-A case Study Bangladesh.

[10] ADB, 2010. Web page of Annual Development Budget in Bangladesh,(www.bengaliwiki.com/page/Development+Budget)

[11] WRW. 2011. Web page of Water Resources Wikipedia (http://en.wikipedia.org/wiki/Water_resources)

[12] Bangladesh Map, 2011. Location map of Bangladesh in World (http://www.mapsofworld.com/bangladesh)

[13] GWP. 2011. Web page of Global Water Partnership (www.gwp.org/en/About-GWP/History)

[14] WARPO, 2011. Web page of Water Resources Planning Organization, Minsitry of Water Resources, Bangladesh. (www.warpo.gov.bd)

[15] BWDB, 2011. Web page of Bangladesh Water Development Board (www.bwdb.gov.bd)

[16] JRC, 2011. Web page of Joint River Commission, Bangladesh (www.jrcb.gov.bd)

[17] DPHE, 2011. Web page of Department of Public Health Engineering, Bangladesh (www.dphe.gov.bd)

[18] LGED, 2011. Web page of Local Government Engineering Department, Bangladeh (www.lged.gov.bd)

[19] DoE, 2011, Web page of Department of Environment, Bangladesh (www.doe-bd.org)

[20] WARPO, 2009. Annual Report 2007-2008, Water Resources Planning organization, Ministry of Water Resources, Government of the People's Republic of Bangladesh.

[21] WARPO, 2009. Annual Report 2007-2008, Water Resources Planning organization, Ministry of Water Resources, Government of the People's Republic of Bangladesh. 
[22] Ahmed, S. (2011), Online questionnaire survey to suahmed@cegisbd.com on Bangladesh Water Management System.

[23] Chowdhury, J.U. (2011), Online questionnaire survey to juc@iwfm.buet.ac.bd on Bangladesh Water Management System.

[24] Rahman, M.R. (2011), Online questionnaire survey to rezaur@iwfm.buet.ac.bd on Bangladesh Water Management System.

[25] Global Water Partnership, 2000. Technical Advisory Committee (TAC) Background Papers, NO. 4, Integrated Water Resources Management, , SE -105 25 Stockholm, Sweden)

[26] Alam, M.M. and Quevauviller, P., 2014. 'A comparative analysis of Bangladesh Water Management Practice with European Water Framework Directives'. Engineering International , Vol: 1, Issue: 1, published by Asian Business Consortium, 3900 Woodhue Place, Alexandria, VA 22309, USA

\section{Call for Paper}

ABC Journal of Advanced research (ABC-JAR) is an open-access, peer-reviewed multidisciplinary journal which seeks articles from any discipline of education. ABC-JAR features reports on current developments in advanced research as well as on related discipline issues. The digital online version is published by ABC-JAR home, ABC USA and the hard copy (print) version is published by $A B C$, Bangladesh. Web: www.abcjar.us
Engineering International (EI) is a peer-reviewed multi-disciplinary international journal devoted to academic advanced research from all aspects of engineering arena. It specializes in the publication of comparative thematic issues as well as individual research articles, review essays, and book reviews. Engineering International is fully and freely accessible on line. Web: www.j-ei.us 


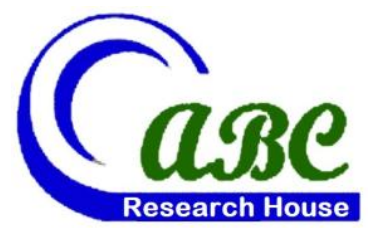

- Rd 4, Shyamoli, Dhaka-1207, Bangladesh

- Pantidalam, Kuala Lampur, Malaysia

- 3900 Woodhue Place, Alexandria, VA 22309, USA

www.abcreorg.weebly.com / www.abcjournals.net

Asian Business Consortium (ABC) is a multi-disciplinary research, training, publishing, digital library supporting and service house. Though founded in 2010 as the Business and Computing organization of Asia, it was reconstituted as the ABC in 2011. It has been working for creating and nurturing talents in USA, Malaysia and Bangladesh since its inception. As ABC is going global, it intends to open chapters in Australia, Germany, Japan, Pakistan, and other Asian countries in near future. The objectives of consortium are solely centered round the welfare and humane attitude of the founders who enthusiastically took up this noble cause and materialized it with a view to promote research and educational activities for the encouragement of scholars to develop their knowledge, to publish their analysis oriented scientific researches in international Journals, books, the task of organizing workshops, seminars, conferences, training, personality development programs and allied services.

In addition to research activities, ABC provides a good number of scholarships to the poor and meritorious students at various levels of education throughout the world. It plays an important role in the field of research by funding research projects and publishing the research papers. This consortium will unquestionably become the mouth-piece of the dark horses and unacknowledged scholar whose endowed and commendable contributions shall be provided an outlet keeping in mind the greater good of the larger society of the world.

$\mathrm{ABC}$ runs the following international referred journals for creating a platform to share the thoughts of professionals, scholars and academicians throughout the world.

\section{ABC Publications (ABC Journals)}

- Asian Accounting and Auditing Advancement (4A Journal); ICV 5.09

- $\quad$ Asian Business Review (ABR); UIF 0.1809

- Asian Journal of Applied Sciences and Engineering (AJASE); UIF 0.6351

- Global Disclosure of Economics and Business (GDEB)

- $\quad$ ABC Journal of Advanced Research (ABC-JAR)

- International Journal of Reciprocal Symmetry and Theoretical Physics (IJRSTP)

- American Journal of Trade and Policy (AJTP)

- Asian Journal of Humanity, Art and Literature (AJHAL)

- $\quad$ ABC Journal of Medical and Biological Research (ABC-JMBR)

- Asia Pacific Journal of Energy and Environment (APJEE)

- $\quad$ Engineering International (EI)

- $\quad$ ABC Research Alert (Online)

Each journal home page provides specific information for potential authors and subscribers. Open access policy, the quick review process, rich editorial boards and quality publications have already made $A B C$ Journals unique. ABC Journals are published under the direct supervisions of renowned academicians of the world.

Collaboration in Conference: $A B C$ considers high-quality conference papers for publication. Please contact us for detailed information.

Collaboration in Publishing: If you like to start writing a book, propose a new journal or advertise in $\mathrm{ABC}$ journals, please feel free to contact us. 


\section{Submit your next manuscript at- www.abcjournals.net}

ABC Journals is a unique forum to offer open access to all of its articles.

Now ABC Journals's portfolio is over ten journals, which publish both online and in print. 